Hechter, O. (1953b). Rev. Canad. Biol. 12, 123.

Hechter, O., Jacobsen, R. J., Schenker, V., Levy, H., Jeanloz, R. W., Marshall, C. W. \& Pincus, G. (1953). Endocrinology, 52, 679.

Hechter, O., Zaffaroni, A., Jacobsen, R. P., Levy, H., Jeanloz, R. W., Schenker, V. \& Pincus, G. (1951). Recent Progr. Hormone Res. 6, 215.

Jones, H. W. jun. \& Wade, R. (1953). Science, 118, 103.

Kielley, W. W. \& Kielley, R. K. (1951). J. biol. Chem. 191, 485.

Mader, W. J. \& Buck, R. R. (1952). Analyt. Chem. 24, 666.
Plager, J. E. \& Samuels, L. T. (1953). Arch. Biochem. Biophys. 43, 476.

Reichstein, T. \& Fuchs, H. G. (1940). Helv. chim. acta, 23, 684.

Sourkes, T. L. \& Heneage, P. (1952). Endocrinology, 50, 73.

Taylor, T. G. (1953). Biochem. J. 54, 48.

Taylor, W. (1954). Biochem. J. 56, 463.

Umbreit, W. W. (1949). In Manometric Techniques and Tissue Metabolism, p. 1, by W. W. Umbreit, R. H. Burris \& J. F. Stauffer. Minneapolis: Burgess Publishing Co.

\title{
The Non-Protein Nitrogen of Extracts of Pisum sativum
}

\author{
By SHEENAH K. BISSET \\ Department of Biochemistry, University College, Dundee, University of St Andrews
}

(Received 15 March 1954)

A number of methods have been used in the past for obtaining non-protein nitrogenous compounds from plant tissues, but little information about their relative efficiencies is available. The present study concerns the extraction of soluble nitrogen-containing compounds from green seed peas by cold and hot saline solutions and by cold and hot water. In these extracts the non-protein nitrogen (NPN) was determined after precipitation by trichloroacetic acid (TCA), ethanol, tungstic acid, colloidal iron and after dialysis. The NPN fractions were analysed for total $\mathrm{N}$ and carboxyl $\mathrm{N}$ (ninhydrincarbon dioxide). The amino acids of the extracts were investigated by paper-partition chromatography.

\section{MATERIAL AND METHODS}

Green seed peas freshly removed from pod were used, the variety Onwards being studied. The green pods, collected approximately 20 days after flowering, were fully swollen and corresponded to stage 12 (Hyde, 1954).

Extraction. Approx. $10 \mathrm{~g}$. of peas were ground in a glass mortar with $20 \mathrm{ml}$. of saline buffer $(\mathrm{pH} \mathrm{7}$ ) of composition $0.2 \mathrm{M}-\mathrm{NaCl}, 0.3 \mathrm{M}-\mathrm{Na}_{2} \mathrm{HPO}_{4}, 0.011 \mathrm{M}-\mathrm{NaH}_{2} \mathrm{PO}_{4}$. The supernatant liquid was decanted and the process repeated with seven successive lots of saline buffer to give a total volume of $140 \mathrm{ml}$. The extracts were centrifuged at $1500 \mathrm{~g}$ for $30 \mathrm{~min}$. and the supernatant fluid was decanted. The extraction with cold distilled water was made in a similar manner. With the hot-saline and hot-water extractions, solutions at $98^{\circ}$ were used.

Precipitation. (a) Trichloroacetic acid. To the pea extract $(20 \mathrm{ml}$.) TCA (1 g.) was added, the mixture was allowed to stand for 45 min., the volume was measured and the mixture filtered.

(b) Ethanol. The pea extract $(20 \mathrm{ml}$.) was mixed with ethanol $(80 \mathrm{ml}$.) and the solution allowed to stand for $24 \mathrm{hr}$. at $2^{\circ}$. It was then filtered. (c) Tungstic acid. To the pea extract $(20 \mathrm{ml}$.) were added $10 \%(\mathrm{w} / \mathrm{v})$ sodium tungstate $\left(20 \mathrm{ml}\right.$.) and $0.66 \mathrm{~N}-\mathrm{H}_{2} \mathrm{SO}_{4}$ $\left(20 \mathrm{ml}\right.$.). The mixture was allowed to stand at $2^{\circ}$ for $24 \mathrm{hr}$. and then filtered.

(d) Colloidal iron. This method was successful only when saline buffer was used as an extracting agent. Pea extract $(10 \mathrm{ml}$.) was mixed with dialysed iron (10 ml.) (British Drug Houses Ltd.) and the solution left for $12 \mathrm{hr}$. at $2^{\circ}$. Water $(40 \mathrm{ml}$.) was then added and the mixture shaken and filtered.

Dialysis. This was carried out by placing $50 \mathrm{ml}$. of the pea extract in a cellophan sac and dialysing against 5-6 vol. of chloroform water for $96 \mathrm{hr}$. at $0-2^{\circ}$ with occasional stirring (Synge, 1951). The diffusate was concentrated in vacuo for further study.

Analytical methods. Nitrogen was determined by the micro-Kjeldahl method of Hiller, Plazin \& Van Slyke (1948). The distillation apparatus of Markham (1942) was employed. In determinations of extractable $\mathrm{N}$ and of NPN, samples containing 0.24-0.47 mg. $\mathrm{N}$ were used. Determinations were in triplicate, and agreed within $\pm 0.5 \%$.

The ninhydrin- $\mathrm{CO}_{2}$ method of Van Slyke, Dillon, MacFadyen \& Hamilton (1941) with minor modifications was used. Pea extract $(2 \mathrm{ml}$.) containing approx. $0.7 \mathrm{mg}$. carboxyl $\mathrm{N}$ was added to each tube. $2 \mathrm{ml}$. water were added in the case of the blank. It was found unnecessary to do blank determinations $\left(\mathrm{CO}_{2}\right.$ without ninhydrin) since these proved to be the same as water blanks. The determinations were made with trioxohydrindene hydrate $(50 \mathrm{mg}$.) and $50 \mathrm{mg}$. citrate buffer ( $\mathrm{pH} \mathrm{2.5)}$ using Thunberg vacuum tubes sealed with stopcock grease as reaction vessels. The various extracts were adjusted to a $\mathrm{pH}$ value suitable for the estimation. TCA was removed from the extract by means of ether, which raised the $\mathrm{pH}$ from 1 to 6 . The ether dissolved in the extract caused an increase in pressure when the tube was evacuated but could be expelled after the $\mathrm{CO}_{2}$ had been collected in the $0.5 \mathrm{~N}-\mathrm{NaOH}$. The ethanol extract was evaporated under reduced pressure at room temperature. The $\mathrm{pH}$ of the tungstic acid filtrate was adjusted to 2.5 by the addition of citrate buffer, excess $\mathrm{CO}_{2}$ being removed by boiling the extract for $3 \mathrm{~min}$. before the addition of

Bioch. 1954, 58 
ninhydrin. No adjustment of $\mathrm{pH}$ was necessary for the extracts obtained after the use of colloidal iron or after dialysis. All determinations were carried out in triplicate; results agreed within $\pm 1^{\circ}$.

To demonstrate the presence of amino acids in the extracts the two-dimensional paper-chromatographic method of Consden, Gordon \& Martin (1944) was used. The solvent systems employed were phenol-ammonia (Dent, 1948) followed by $n$-butanol-acetic acid-water (4:1:5 by vol.) (Partridge, 1948).

Before chromatography was carried out, the extracts were treated as follows: (a) TCA when present was removed by repeated extraction with ether; (b) saline extracts were desalted (Consden, Gordon \& Martin, 1947); (c) the treated solutions were concentrated in vacuo and the residues made up to a known volume with water. In each case the same volume was applied to the paper. The sodium tungstate extract was unsuitable for chromatography since the tungstate could not be removed. The amino acids were detected after drying by spraying with $0.1 \%(\mathrm{w} / \mathrm{v}) \mathrm{nin}-$ hydrin in ethanol.

\section{RESULTS}

The values for extractable $\mathrm{N}$ and for NPN in the various extracts following the use of the different treatments are given in Table 1 . The results show that hot-saline extraction followed by TCA precipitation is the most effective method of extracting NPN from pea seeds. Extraction of NPN after ethanol precipitation is more effective when saline is used as the extracting agent, considerable adsorption of amino acids by protein taking place if water is used. Tungstic acid precipitation gives rise to low NPN values, since it appears that 'basic' nitrogen is precipitated by the acid. The colloidal-iron precipitation of protein is effective only if saline buffer is present. Dialysis, after extraction of the peas by either saline or water, gives similar values for NPN.

The results obtained in the determination of the carboxyl nitrogen in the extracts are given in Table 2. The values show that hot-saline extraction followed by TCA precipitation is an effective method of obtaining $\alpha$-amino acids. Tungstic acid precipitation after hot-saline extraction gives the highest carboxyl $\mathrm{N}$ values. This may be due to precipitation and adsorption of the basic nitrogen by the protein thus leaving a higher percentage of $\alpha$-amino acids in solution. With the other treatments hot-saline extracts have the higher carboxyl $\mathrm{N}$ values.

Chromatography. The following amino acids were recognized in all the extracts : aspartic acid, glutamic acid, serine, glycine, threonine, homoserine, alanine, $\alpha$ - and $\gamma$-aminobutyric acids, valine, methionine, leucine + isoleucine, proline, $\beta$-alanine, lysine, phenylalanine, citrulline, asparagine and glutamine. Three unidentified amino acids were present. Cysteic acid and pipecolinic acid were also probably present.

Differences in the extracts were as follows. With hot-saline extraction followed by TCA precipitation there was more glutamine, glutamic acid, serine, valine and leucine. No marked differences were obtained with hot- and cold-water and cold-saline extracts after TCA treatment.

The extracts after ethanol precipitation showed that hot- and cold-saline solutions remove more amino acids than do hot and cold water.

With colloidal-iron precipitation the extraction is only effective in the presence of saline. The chromatograms show that hot saline is more effective in extracting amino acids than is cold saline.

The chromatograms obtained using the dialysed extracts show that, although there is no difference between the extractions with hot saline and hot water, they both give better extractions than do cold solutions.

Table 1. Comparison of the different media used for extraction of non-protein nitrogen (NPN) from pea seeds

Total N/g. of seeds was $11.7 \mathrm{mg}$. Extractions are expressed as mg./g. green seeds (from triplicate estimations).

\begin{tabular}{|c|c|c|c|c|c|c|}
\hline \multirow[b]{2}{*}{ Extracting medium } & \multirow{2}{*}{$\begin{array}{c}\text { Total } \\
\text { extractable } \\
\mathbf{N}\end{array}$} & \multicolumn{5}{|c|}{ NPN in extracts after } \\
\hline & & $\begin{array}{l}\text { Trichloro- } \\
\text { acetic acid }\end{array}$ & Ethanol & $\begin{array}{l}\text { Tungstic } \\
\text { acid }\end{array}$ & $\begin{array}{l}\text { Colloidal } \\
\text { iron }\end{array}$ & Dialysis \\
\hline $\begin{array}{l}\text { Cold saline buffer } \\
\text { Cold water } \\
\text { Hot saline buffer } \\
\text { Hot water }\end{array}$ & $\begin{array}{l}9 \cdot 0 \\
9 \cdot 0 \\
7 \cdot 6 \\
7 \cdot 2\end{array}$ & $\begin{array}{l}4 \cdot 5 \\
4 \cdot 2 \\
5 \cdot 7 \\
4 \cdot 6\end{array}$ & $\begin{array}{l}4 \cdot 2 \\
3 \cdot 2 \\
5 \cdot 5 \\
3 \cdot 9\end{array}$ & $\begin{array}{l}3 \cdot 6 \\
2 \cdot 8 \\
4 \cdot 7 \\
3 \cdot 0\end{array}$ & $\frac{4 \cdot 4}{5 \cdot 3}$ & $\begin{array}{l}4 \cdot 0 \\
4 \cdot 1 \\
4 \cdot 8 \\
4 \cdot 7\end{array}$ \\
\hline
\end{tabular}

Table 2. Free amino acids after action of extracting agents and protein precipitants

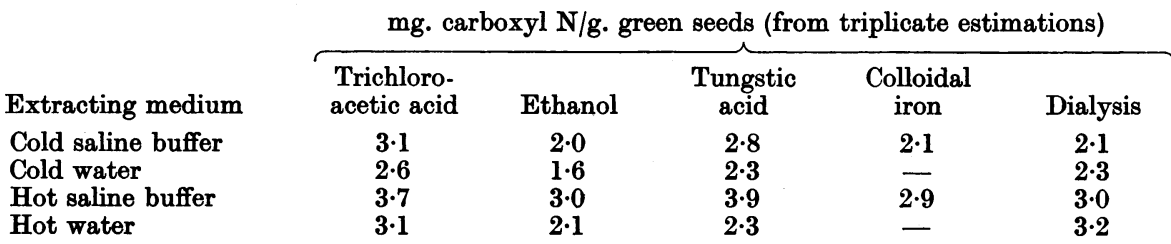




\section{DISCUSSION AND SUMMARY}

Green seed peas were extracted with hot and cold saline buffer and with hot and cold water. The protein was removed from these extracts by trichloroacetic acid, ethanol, tungstic acid and colloidal iron; diffusates were also prepared by dialysis of the extracts. Cold water and saline extracted more nitrogen-containing compounds, but the best yields of non-protein nitrogen were obtained by hot-saline extraction followed by trichloroacetic acid precipitation. Ethanol and colloidal iron gave good recoveries after a similar extraction, but the amounts yielded by tungstic acid precipitation and by dialysis were less. This action of precipitants is similar to that observed by Steward \& Street (1946) in their survey of the soluble-nitrogen fractions of the potato tuber.

The amount of free amino acid was high in the hot-saline extract after trichloroacetic acid precipitation but the highest values were obtained after tungstic acid precipitation.

Paper chromatography of the extracts showed the presence of numerous amino acids. Tungstic acid filtrates are unsuitable for chromatography.
It is suggested that, for a complete extraction of non-protein nitrogen from peas, hot saline-buffer extraction followed by trichloroacetic acid precipitation is the best procedure. Excess trichloroacetic acid may be easily removed by extraction with ether. The procedure of next choice would appear to be the use of ethanol.

I thank Dr R. P. Cook for his supervision of this investigation. Part of the expenses of this work was defrayed from the Agricultural Research Council funds.

\section{REFERENCES}

Consden, R., Gordon, A. H. \& Martin, A. J. P. (1944). Biochem. J. 38, 224.

Consden, R., Gordon, A. H. \& Martin, A. J. P. (1947). Biochem. J. 41, 590.

Dent, C. E. (1948). Biochem. J. 43, 169.

Hiller, A., Plazin, J. \& Van Slyke, D. D. (1948). J. biol. Chem. 176, 1401.

Hyde, T. G. (1954). Proc. Roy. Soc. Edinb. (in the Press). Markham, R. (1942). Biochem. J. 36, 790.

Partridge, S. M. (1948). Biochem. J. 42, 238.

Steward, F. C.\& Street, H. E. (1946). Plant Physiol. 21, 155. Synge, R. L. M. (1951). Biochem. J. 49, 642.

Van Slyke, D. D., Dillon, R. T., MacFadyen, D. A. \& Hamilton, P. (1941). J. biol. Chem. 141, 627.

\title{
The Liberation of Aspartic Acid during the Acid Hydrolysis of Proteins
}

\author{
By S. BLACKBURN AND G. R. LEE \\ Wool Industries Research Association, Torridon, Headingley, Leeds 6
}

(Received 6 October 1953)

Comparatively little is known about the relative rates of hydrolysis of the different peptide bonds in proteins, or about the effect on these rates of changes in hydrolytic conditions (cf. Acher, Jutisz \& Fromageot, 1950; Desnuelle \& Casal, 1948). Partridge \& Davis (1950) found that when a number of proteins were hydrolysed with boiling weak acids, aspartic acid was liberated in the free state much sooner than other amino acids, and later Blackburn $(1950 a)$ showed that aspartic acid was also preferentially liberated during hydrolysis of proteins with dilute solutions of strong acids at the boil.

The present paper is concerned with the liberation of aspartic acid under various conditions of acid hydrolysis, and the extent to which this liberation occurs independently of the splitting of other linkages. A mechanism for the liberation is suggested.

\section{MATERIALS AND METHODS}

A '56s' quality virgin wool (Blackburn, Consden \& Phillips, 1944) was used in the first experiments. As the supply of this wool became exhausted, a '64s A' quality Australian wool was cleaned in a similar manner and used in the later experiments. Crystallized bovine plasma albumin was obtained from Armour Laboratories.

Partial hydrolysis and estimation of free amino acids. The wool or other protein was hydrolysed with $\mathrm{HCl}(100 \mathrm{ml} . / \mathrm{g}$. under the conditions stated below, any undissolved wool filtered off and excess of acid removed by repeated distillation in vacuo below $40^{\circ}$, with successive additions of water. The hydrolysates were examined on phenol- $\mathrm{NH}_{3}$, collidine, or two-dimensional collidine/phenol- $\mathrm{NH}_{3}$ chromatograms, the concentration of the free amino acids being estimated by visual observation of the size and intensity of the amino acid spots on the chromatogram. The $x$ 's of Table 1 have the significance attached to them by Consden, Gordon, Martin \& Synge (1947) and Consden, Gordon \& Martin (1949), and give a semiquantitative estimate of the amounts of the amino acids. Proline was detected by the isatin reaction (Acher, Fromageot \& Jutisz, 1950) and cystine by oxidation to cysteic acid with hydrogen peroxide (Dent, 1948). The concentration of free aspartic acid in some of the hydrolysates was measured by the method of Blackburn \& Robson (1953). The peptides present in the partial hydrolysates had very small $R_{F}$ values and were far removed from the aspartic acid spot, and other free amino acids were only present in traces. It was therefore possible to estimate the aspartic acid on one-dimensional phenol- $\mathrm{NH}_{3}$ chromato- 